\title{
On the use of observational data in studying biodiversity-productivity relationships in forests
}

\author{
by Xiuli Chu ${ }^{1}$, Hua Yang ${ }^{2}$, Yong Jiang ${ }^{3}$, Rongzhou Man4*
}

\begin{abstract}
The biodiversity-productivity relationship is one of the focus areas in ecological research that is studied primarily through mixed species experiments. Recent efforts in forests, however, increasingly involve the use of observational data, due to the difficulty in establishing long-term, multispecies plantations. Caution is warranted in the observational databased causal relationships between biodiversity and productivity due to the potential confounding effects by environmental variations. In this article, we use a recent forest example to demonstrate how erroneous results could be generated in studying biodiversity-forest productivity relationships when species diversity is highly correlated with environmental variables (multicollinearity). In forestry, erroneous biodiversity-productivity relationships can mislead future research, industry decisions, and policy development. Forest researchers and managers should be aware of the issues associated with collinear data and validate research results with literature reports and professional knowledge. Options to deal with observational data are discussed.
\end{abstract}

Key words: species richness; confounding variables; regression analysis; causal effects; multicollinearity

\section{RÉSUMÉ}

La relation biodiversité-productivité est l'un des domaines où la recherche écologique se fait principalement sur la base d'expérimentations dans des peuplements mélangés. Cependant, les travaux de recherche récents en forêt reposent de plus en plus l'utilisation de données d'observation, en raison de la difficulté d'établir des plantations mixtes sur des horizons assez longs. On doit donc faire preuve de grande prudence lorsqu'on utilise des données d'observation pour établir des relations de causalité entre la biodiversité et la productivité en raison du risque de confusion que peut induire la variabilité environnementale. Cet article s'appuie sur un exemple récent en milieu forestier pour démontrer comment il est possible d'en arriver à des résultats erronés dans l'étude des relations entre la biodiversité et la productivité de la forêt lorsque la diversité des espèces est fortement corrélée à des variables environnementales (multicolinéarité). En foresterie, les relations biodiversité-productivité erronées peuvent être la source d'erreurs dans de futures recherches, dans les décisions de l'industrie et pour l'élaboration des politiques. Les chercheurs et les gestionnaires forestiers doivent être conscients des problèmes associés aux données colinéaires et confronter les résultats des recherches à d'autres rapports scientifiques et au savoir professionnel. Cet article analyse diverses options pour l'utilisation des données d'observation.

Mots-clés : diversité des espèces; variables parasites; analyse de régression; effet de causalité; multicolinéarité

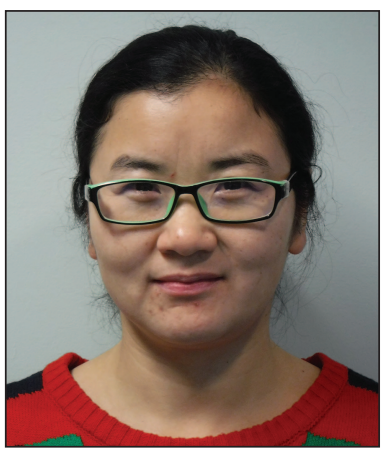

Xiuli Chu

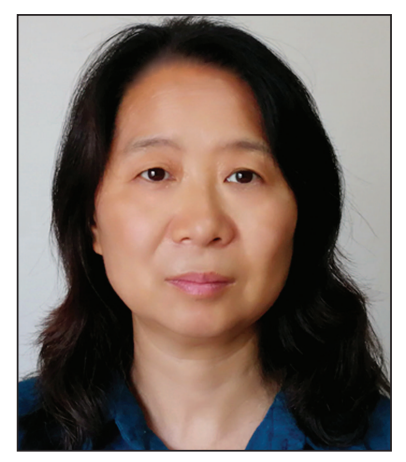

Hua Yang

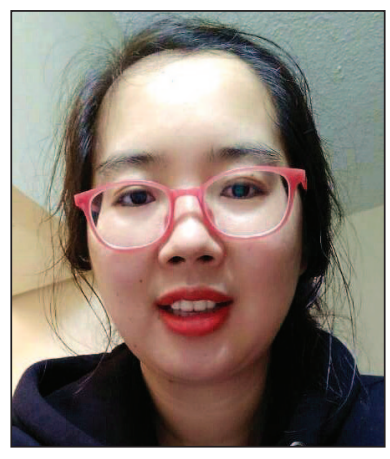

Yong Jiang

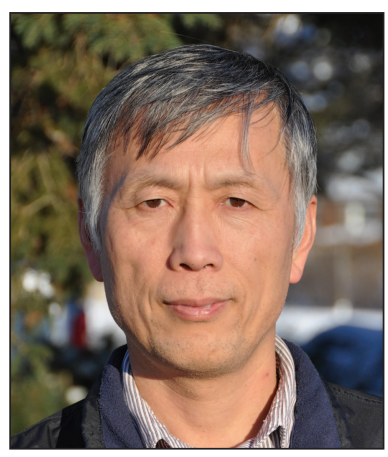

Rongzhou Man

\footnotetext{
${ }^{1}$ Research Institute of Subtropical Forestry, Chinese Academy of Forestry, Zhejiang, China

${ }^{2}$ College of Forestry, Beijing Forestry University, Beijing, China

${ }^{3}$ Yong Jiang, Key laboratory of Ecology of Rare and Endangered Species and Environmental Protection of Ministry of Education, Guangxi Normal University, China

${ }^{4}$ Ontario Forest Research Institute, Ontario Ministry of Natural Resources and Forestry, Sault Ste. Marie, Canada; ${ }^{\star}$ Corresponding author: rongzhou.man@ontario.ca
} 


\section{Introduction}

The proper estimation of biodiversity-productivity relationships in forests is critical in understanding the impacts of biodiversity loss on ecosystem services and functions (Liang et al. 2016a) and the role of forests in mitigating the influences of climate change (Huang et al. 2018). In grassland ecosystems, the effect of biodiversity on productivity has been commonly examined through controlled mixed species experiments (Tilman et al. 2012). In forest ecosystems, mixed species plantations were generally used in an early effort of comparing the productivity of mixed versus single species stands (Vandermeer 1989; Kelty et al. 1992). Recently, both mixed species plantations and observational data are involved (Vila et al. 2003, 2007, 2013; Belote et al. 2011; RuizBenito et al. 2014; Liang et al. 2016a, 2016b; Chen et al. 2018), due to the difficulty in establishing long-term, multispecies plantations and the increasing needs in understanding biodiversity-productivity relationships under different climate and site conditions (Vila et al. 2007; Morin et al. 2011).

\section{Results of experimental testing}

The yield differences between mixed and single species stands have long been of interest in forestry (Assmann 1970; Man and Lieffers 1999; Pretzsch 2005; Forrester and Pretzsch 2015) and examined primarily through experimental planting (Vandermeer 1989; Kelty et al. 1992). Early efforts typically involved the comparison of monocultures with 2-species mixtures, with the establishment of multispecies experiments occurring more recently (Huang et al. 2018). Estimates of species richness effects on forest productivity have been variable from positive to negative depending on many stand and site factors (Man and Lieffers 1999; Pretzsch 2005; Vilà et al. 2005; Knoke et al. 2008; Cavard et al. 2010; Forrester and Pretzsch 2015; Bauhus et al. 2017). As such, a tree mixture of significant productivity gain is often less productive or neutral when implemented over different stand and site conditions (Pretzsch 2005; Vilà et al. 2005; Forrester and Pretzsch 2015). This trend is also demonstrated with the decreasing productivity gains by increasing scale of meta-analyses in comparison of mixed versus single species stands, e.g., from $60 \%$ for eight study sites (Hulvey et al. 2013) to $24 \%$ for 54 study sites (Zhang et al. 2012), and to 15\% for 60 study sites (Jactel et al. 2018).

Although not tested for complete species assemblages of natural forests under different climate conditions, a possible tree species richness-forest productivity relationship represents an asymptotic curve, i.e., productivity increases with species richness in a decelerating pattern (Zhang et al. 2012; Vila et al. 2013; Ruiz-Benito et al. 2014; Ammer 2018; Huang et al. 2018). The maximum productivity reached and levels of species richness at which the curves become saturated depend on many factors (Ammer 2018). This suggests that the species richness-productivity relationship of natural forests would not decrease substantially in response to tree species loss until species richness is reduced below a critical threshold (i.e., 40-50\%) (Hooper et al. 2012).

\section{Examinations with observational data}

Broad-scale species richness and ecosystem productivity is shown to be driven by climate (Currie and Paquin 1987;
Wang et al. 2009; Toledo et al. 2011; Hlásny et al. 2017). Typically, species richness and productivity increase with temperature (Allen et al. 2002; Wang et al. 2009; Toledo et al. 2011) and precipitation (Toledo et al. 2011; Jucker et al. 2016); more productive environments support more vigorous growth of individuals and higher numbers of species (Allen et al. 2002; Gillman and Wright 2006). Such climatedriven patterns are influenced by regional topography (Wang et al. 2009), historical factors (Guo 1999; Tilman et al. 2012), and local soil conditions (Toledo et al. 2011; Ammer 2018). As species richness is strongly influenced by the environment, the use of observational data with multiple regression is associated with a fundamental drawback - the uncertainty of causal relationship between biodiversity and productivity due to confounding heterogeneous forest and environment conditions (Belote et al. 2011; Vilà et al. 2013; Jucker et al. 2016). This issue is clearly discussed in statistical textbook (Neter et al. 1996), but often ignored in the analyses of ecological data and can lead to inconsistent, erroneous findings (Graham 2003; Dormann et al. 2013), especially with largescale analyses across significant environmental gradients.

Using global forest permanent sample plot data and multiple regression, Liang et al. (2016a) showed that, with all other variables held constant at global averages, biodiversity (species richness) contributes $340 \%$ to the change in forest productivity. Such a strong species richness effect is not supported by the results of mixed species experiments (Huang et al. 2018; Jactel et al. 2018) or the analysis of observational data (Vilà et al. 2013; Ruiz-Benito et al. 2014), and is impossible to achieve with modern forestry practices.

If the multicollinear effect by the relative response of global forests to species richness change is not obvious, the absolute productivity change in a specific forest region can be used to better demonstrate the flawed species richness effects reported by Liang et al. (2016a). In the boreal forest region, Liang et al. (2016a) indicated an average of $100 \%$ productivity increase from 2.7 to $5.4 \mathrm{~m}^{3} \mathrm{ha}^{-1}$ year ${ }^{-1}$ with species richness 1-15. In the Canadian boreal forest, which represents about one third of circumpolar boreal forests, such species richness-driven productivity change would only be possible if low species richness and low productivity forests, (e.g., jack pine forests on extremely dry sites and black spruce forests on wetlands), are compared with high species richness and high productivity mixedwood forests on medium sites, without consideration of site differences. On mixedwood sites, mixed species stands generally have higher productivity than single species stands, but the differences found, by planned experiments or examination of natural forests, are generally $<30 \%$ (Man and Lieffers 1999; MacPherson et al. 2001; Man and Greenway 2013). The expected species richness effect would only decrease over large areas within or across ecoregions, since the tree species richness effect on forest productivity is not always positive and thus averages out (Man and Lieffers 1999; Ammer 2018; Jactel et al. 2018).

Similarly, Liang et al. (2016a) suggested an average of $200 \%$ productivity increase with species richness $1-70$ and an additional $120 \%$ increase with species richness $70-270$ in the tropical moist broadleaf forests. Again, these results are inconsistent with what ecologists generally expect, according to Hubbell's neutral theory of biodiversity (Matthews and 
Whittaker 2014), that tree species in the world's most diverse forests are functionally equivalent and that hence there should be little, if any, productivity change from changing species richness from 70 to 270 .

The reason for such erroneous findings is the confounding effect or multicollinearity in which trees species richness is significantly correlated with annual precipitation, precipitation of warmest quarter, and indexed annual aridity in the forest productivity model developed by Liang et al. (2016a). Although the overall model, associated statistics, and even predictions may not be negatively affected, the reliable assessment of species richness effect becomes difficult, if not impossible (Neter et al. 1996; Dormann et al. 2013). As species richness effect cannot be separated from those of confounding variables, the change of productivity with species richness while holding all other explanatory variables constant (Liang et al. 2016a) does not result in a meaningful relationship between species richness and forest productivity, as would be in the situations where explanatory variables are not correlated (Neter et al. 1996; Graham 2003; Dormann et al. 2013). Liang et al. (2016a) showed an insignificant correlation between productivity and species richness (see their Fig. 6A), suggesting that species richness effect is likely insignificant. As such, the species richness effect claimed by Liang et al. (2016a) more likely represent the variations of forest productivity across different climate zones of the world forests. The presented species richness-productivity curve continues to increase to full species richness, which is consistent with global environment changes and in sharp contrast with the plantation data-based species richness-productivity curves that quickly become saturated at relatively low species richness (Zhang et al. 2012; Ammer 2018; Huang et al. 2018). The subsequent predictions of forest productivity decrease with tree species loss, therefore, considerably exceed those illustrated in the plantation data-based species richness-productivity relationship (Table 1).

Attributing causal effect with observational data using regression analysis is difficult, if not impossible, and conclusions are often flawed (see Duffy et al. 2017 for a similar mistake). Biodiversity and productivity are ecosystem functions, both positively associated with environmental temperature and precipitation (Rosenzweig 1995; Hawkins et al. 2003; Allen et al. 2002; Wang et al. 2009; Toledo et al. 2011), and therefore positively correlated. However, correlation does not imply a causal mechanism (Neter et al. 1996; Rawlings et al. 1998; Binkley and Menyailo 2005; Forrester and Pretzsch 2015). In an earlier effort by Liang et al. (2016b), explanatory and response variables were switched and, of course, a significant pattern was shown between the explanatory variable (productivity) and response variable (species richness). Then they attempted to attribute causal effect of productivity on species richness and began to speculate on a possible twoway causality (Liang et al. 2016a) that has been only experimentally examined through fertilization in grassland ecosystems (Grace et al. 2016).

Jactel et al. 2018)

\section{Caution with use of observational data}

Although the results of Liang et al. (2016a) are inconsistent to ecological theories that plant diversity and productivity are influenced predominantly by climate (Currie and Paquin 1987; Hlásny et al. 2017), the study has been cited over 200 times in two years by many top ecological, environmental, forestry, and biological journals including Science and Nature, while being heavily advocated in social media (search on Google on October 27, 2018). Apparently, many readers are unaware of the multicollinear issues with respect to observational data or do not fully comprehend the methods used by Liang et al. (2016a). That being said, researchers who hold some accountability should be cautious with the use of observational data, check multicollinearity, and validate findings with literature reports and professional knowledge. Unfortunately, erroneous findings in forestry research can mislead future research, industry decisions, and policy development-other researchers using Liang et al. (2016a) methods and results will continue to produce erroneous results and forest industry and government respond with increased investment in multispecies plantations with the expectations of greater timber production, biomass, or carbon sequestration. Since forestry is a long-term investment, considerable time could pass before the realization that the return of increased productivity suggested by Liang et al. (2016a) is unachievable.

While the statistical recommendations to drop explanatory variables that are highly correlated with others or use principle components regression (Neter et al. 1996; Quinn and Keough 2002; Graham 2003) are apparently not feasible options in studying biodiversity-productivity relationships with multiple regression, some statistical techniques are available for diagnosing and remediating the effects of multicollinearity (Quinn and Keough 2002; Graham 2003). Analyses can also be conducted at smaller spatial scales, such as ecoregion or forest type (Vila et al. 2003, 2007, 2013; Belote et al. 2011; Ruiz-Benito et al. 2014; Chen et al. 2018) to control for the confounding environmental variations. Even with some control measures, caution is required in result interpretation because of the potential confounding effects, for example, by different successional stages and canopy closure (Vila et al. 2003, 2007) and local soil conditions (Toledo et al. 2011; Ammer 2018). With the use of collinear data, attempts must be made to explore the functional nature of the collinearities

Table 1. Decreases of forest productivity under different scenarios of tree species loss

\begin{tabular}{ll}
\hline Prediction method & Level of tree species loss \\
\hline $\begin{array}{c}\text { Minimum } \\
(10 \% \text { loss })\end{array}$ & $\begin{array}{l}\text { Maximum (conversion of world } \\
\text { forests to monocultures) }\end{array}$
\end{tabular}

Observational data-based species richness- $\quad 2.1-3.1 \% \quad 26-66 \%$

productivity model (Liang et al. 2016a)

Plantation data-based species richnessproductivity model (Hooper et al. 2012, Zhang et al. 2012, Vilà et al. 2013,

Ammer 2018, Huang et al. 2018, 
and avoid presenting results that could mislead investigators and decision-makers, especially given the growing interest in the impacts of tree species loss and roles of forests in mitigating the influences of climate change. Some alternative analyses such as structural equation modelling (SEM) are also available for examining causal relationships with collinear data (Iriondo et al. 2003; Pearl 2012). However, SEM only provides relative strengths of relationships among variables (hypothesis testing), and therefore, does not offer quantitative predictions of causal effects as with mixed species experiments or regression analysis.

\section{Acknowledgements}

The authors acknowledge the editorial contributions from Lisa Buse and Mya Rice of the Ontario Ministry of Natural Resources and Forestry (OMNRF), the financial support from OMNRF, Canada to R.M. and Special Funds for the Basic Scientific Research Service of the Central Public Welfare Research Institute, China to X.C. (CAFYBB2018GC003).

\section{References}

Allen, A.P., J.H. Brown and J.F. Gillooly. 2002. Global biodiversity, biochemical kinetics, and the energetic-equivalence rule. Science 297: 1545-1548.

Ammer, C. 2018. Diversity and forest productivity in a changing Climate. New Phytol. doi:10.1111/nph.15263.

Assmann, E. 1970. Principles of forest yield study. Oxford, UK: Pergamon Press.

Bauhus, J., D.I. Forrester and H. Pretzsch. 2017. From observations to evidence about effects of mixed-species stands. In: H. Pretzsch, D.I. Forrester and J. Bauhus (Eds.). Mixed-species forests Ecology and Management. pp. 27-71. Berlin, Germany: Springer.

Belote, R.T., S. Prisley, R.H. Jones, M. Fitzpatrick and K. Beurs. 2011. Forest productivity and tree diversity relationships depend on ecological context within mid-Atlantic and Appalachian forests (USA). For. Ecol. Manage. 261: 1315-1324.

Binkley, D. and O. Menyailo. 2005. Gaining insights on the effects of tree species on soils. In D. Binkley and O. Menyailo (Eds.). Tree Species Effects on Soils: Implications for Global Change. pp. 1-16. NATO Science Series, Kluwer Academic Publishers, Dordrecht. Cavard, X., Y. Bergeron, H.Y.H. Chen and D. Paré. 2010. Mixedspecies effect on tree aboveground carbon pools in the east-central boreal forests. Can. J. For. Res. 40: 37-47.

Chen, S., W. Wang, W. Xu, Y. Wang, H. Wan, D. Chen, Z. Tang, X. Tang, G. Zhou, Z. Xie, D. Zhou, et al. 2018. Plant diversity enhances productivity and soil carbon storage. Proc. Natl. Acad. Sci. USA 115: 4027-4032.

Currie, D.J. and V. Paquin. 1987. Large-scale biogeographical patterns of species richness of trees. Nature 329: 326-327.

Dormann, C.F., J. Elith, S. Bacher, C. Buchmann, G. Carl, G. Carré, J.R.G. Marquéz, B. Gruber, B. Lafourcade, P.J. Leitão, T. Münkemüller, et al. 2013. Collinearity: A review of methods to deal with it and a simulation study evaluating their performance. Ecography 36: 27-46.

Duffy, J.E., C.M. Godwin and B.J. Cardinale. 2017. Biodiversity effects in the wild are common and as strong as key drivers of productivity. Nature 549 (7671): 261-264.

Forrester, D.I. and H. Pretzsch. 2015. Tamm Review: On the strength of evidence when comparing ecosystem functions of mixtures with monocultures. For. Ecol. Manage. 356: 41-53.

Gillman, L.N. and S.D. Wright. 2006. The influence of productivity on the species richness of plants: A critical assessment. Ecology 87: 1234-1243.
Graham, M.H. 2003. Confronting multicollinearity in ecological multiple regression. Ecology 84: 2809-2815.

Grace, J.B., T.M. Anderson, E.W. Seabloom, E.T. Borer, P.B. Adler, W.S. Harpole, Y. Hautier, H. Hillebrand, E.M. Lind, M. Pärtel, J.D. Bakker, et al. 2016. Integrative modelling reveals mechanisms linking productivity and plant species richness. Nature 529: 390-393.

Guo, Q. 1999. Ecological comparisons between eastern Asia and North America: historical and geographical perspectives. J. Biogeogr. 26: 199-206.

Hawkins, B.A., R. Field, H.V. Cornell, D.J. Currie, J.-F. Guégan, D.M. Kaufman, J.T. Kerr, G.G. Mittelbach, T. Oberdorff, E.M. O'Brien, E.E. Porter and J.R.G. Turner. 2003. Energy, water, and broad-scale geographic patterns of species richness. Ecology 84: 3105-3117.

Hlásny, T., J. Trombik, M. Bošela, J. Merganič, R. Marušák, V. Šebeň, P. Štěpánek, J. Kubišta and M. Trnka. 2017. Climatic drivers of forest productivity in Central Europe. Agri. For. Meteor. 234-235: 258-273.

Hooper, D.U., E.C. Adair, B.J. Cardinale, J.E.K. Byrnes, B.A. Hungate, K.L. Matulich, A. Gonzalez, J.E. Duffy, L. Gamfeldt and M.I. O'Connor. 2012. A global synthesis reveals biodiversity loss as a major driver of ecosystem change. Nature 486: 105-108.

Huang, Y., Y. Chen, N. Castro-Izaguirre, M. Baruffol, M. Brezzi, A. Lang, Y., Li, W. Härdtle, G. von Oheimb, X. Yang, X. Liu, et al. 2018. Impacts of species richness on productivity in a large-scale subtropical forest experiment. Science 362: 80-83.

Hulvey, K.B., R.J. Hobbs, R.J. Standish, D.B. Lindenmayer, L. Lach and M.P. Perring. 2013. Benefits of tree mixes in carbon plantings. Nature Clim. Change 3: 869-874.

Iriondo, J.M., M.A. Albert and A. Escudero. 2003. Structural equation modelling: An alternative for assessing causal relationships in threatened plant populations. Biol. Conserv. 113: 367-377.

Jactel, H., E.S. Gritti, L. Drössler, D.I. Forrester, W.L. Mason, X. Morin, H. Pretzsch and B. Castagneyrol. 2018. Positive biodiversity-productivity relationships in forests: Climate matters. Biol. Lett. 14: doi: 10.1098/rsbl.2017.0747.

Jucker, T., D. Avăcăriței, I. Bărnoaiea, G. Duduman, O. Bouriaud and D.A. Coomes. 2016. Climate modulates the effects of tree diversity on forest productivity. J. Ecol. 104, 388-398.

Kelty, M.J., B.C. Larson and C.D. Oliver. 1992. The ecology and silviculture of mixed-species forests. Dordrecht, English: Kluwer Academic Publishers.

Knoke, T., C. Ammer, B. Stimm and R. Mosandl. 2008. Admixing broadleaved to coniferous tree species: A review on yield, ecological stability and economics. Eur. J. For. Res. 127, 89-101.

Liang, J., T.W. Crowther, N. Picard, S. Wiser, M. Zhou, G. Alberti, E.-D. Schulze, A.D. McGuire, F. Bozzato, H. Pretzsch, S. de-Miguel, et al. 2016a. Positive biodiversity-productivity relationship predominant in global forests. Science 354(6309): aaf8957.

Liang, J., J.V. Watson, M. Zhou and X. Lei. 2016b. Effects of productivity on biodiversity in forest ecosystems across the United States and China. Conserv. Biol. 30: 308-317.

MacPherson, D.M., V.J. Lieffers and P.V. Blenis. 2001. Productivity of aspen stands with and without a spruce understory in Alberta's boreal mixedwood forests. For. Chron. 77: 351-356.

Man, R. and V.J. Lieffers. 1999. Are mixtures of aspen and white spruce more productive than single species stands? For. Chron. 75: 505-513.

Man, R. and K.J. Greenway. 2013. Effects of soil moisture and species composition on growth and productivity of trembling aspen and white spruce in planted mixtures: Five-year results. New For. 44: $23-38$. 
Matthews, T.J. and R.J. Whittaker. 2014. Neutral theory and the species abundance distribution: recent developments and prospects for unifying niche and neutral perspectives. Ecol. Evol. 4: 22632277.

Morin, X., L. Fahse, M. Scherer-Lorenzen and H. Bugmann. 2011. Tree species richness promotes productivity in temperate forests through strong complementarity between species. Ecol. Lett. 14: 1211-1219.

Neter, J., M.H. Kutner and C.J. Nachtsheim. 1996. Applied linear statistical models, 4 th ed., Toronto, Canada: IRWIN.

Pearl, J. 2012. The causal foundations of structural equation modeling. In: R.H. Hoyle (ed.), Handbook of structural equation modeling. pp. 68-91. New York, USA: Guilford Press.

Pretzsch, H. 2005. Diversity and productivity in forests: evidence from long-term experimental plots. In: M. Scherer-Lorenzen, C. Körner and E.D. Schulze (Eds.). Forest Diversity and Function: Temperate and Boreal systems. pp. 41-64. Berlin, Germany: Springer.

Quinn, G.P. and M.J. Keough. 2002. Experimental design and data analysis for biologists. Cambridge, UK: Cambridge University Press.

Rawlings, J.O., S.G. Pantula and D.A. Dickey. 1998. Applied Regression Analysis: A Research Tool (2nd ed.). Springer, New York.

Rosenzweig, M.L. 1995. Species Diversity in Space and Time. Cambridge Univ Press, Cambridge.

Ruiz-Benito, P., L. Gómez-Aparicio, A. Paquette, C. Messier, J. Kattge and M.A. Zavala. 2014. Diversity increases carbon storage and tree productivity in Spanish forests. Glob. Ecol. Biogeogr. 23: 311-322.

Tilman, D., P.B. Reich and F. Isbell. 2012. Biodiversity impacts ecosystem productivity as much as resources, disturbance, or herbivory. Proc. Natl. Acad. Sci. U.S.A. 109: 10394-10397.
Toledo, M., L. Poorter, M. Peña-Claros, A. Alarcón, J. Balcázar, C. Leaño, J.C. Licona, O. Llanque, V. Vroomans, P. Zuidema and F. Bongers. 2011. Climate is a stronger driver of tree and forest growth rates than soil and disturbance. J. Ecol. 99: 254-264.

Vandermeer, J. H. 1989. The ecology of intercropping. Cambridge, UK: Cambridge University Press.

Vila, M., J. Vayreda, C. Graci and J.J. Ibánez. 2003. Does tree diversity increase wood production in pine forests? Oecologia 35: 299-303.

Vilà, M., P. Inchausti, J. Vayreda, O. Barrantes, C. Gracia, J.J. Ibáñez and T. Mata. 2005. Confounding factors of the association between tree diversity and stemwood production. In: M. SchererLorenzen, C. Körner and E.D. Schulze (Eds.). Forest Diversity and Function: Temperate and Boreal systems. pp. 65-86. Berlin, Germany: Springer.

Vila, M., J. Vayreda, L. Comas, J. Ibanez, T. Mata and B. Obon. 2007. Species richness and wood production: A positive association in Mediterranean forests. Ecol. Lett. 10, 241-250.

Vilà, M., A. Carrillo-Gavilán, J. Vayreda, H. Bugmann, J. Fridman, W. Grodzki, J. Haase, G. Kunstler, M. Schelhaas and A. Trasobares. 2013. Disentangling biodiversity and climatic determinants of wood production. PLoS One 8: e53530.

Wang, Z., J.H. Brown, Z. Tang and Fang, J. 2009. Temperature dependence, spatial scale, and tree species diversity in eastern Asia and North America. Proc. Natl. Acad. Sci. U.S.A. 106, 13388-13392. Zhang, Y., H.Y.H. Chen and P.B. Reich 2012. Forest productivity increases with evenness, species richness and trait variation: A global meta-analysis. J. Ecol. 100: 742-749. 